Folia primat. 1971;16:I-IV

\title{
Contents, Vol. 16, 1971
}

Editor:

J. Biegert, Zurich

Editorial Board:

E. L. Bone, Louvain

W. Fiedler, Wien

H. F. Harlow, Madison, Wise.

H. Hediger, Zurich

W. C. Osman Hill, Folkestone

H. Hofer, Covington, La.

J. Hürzeler, Basel

J. R. Napier, London

J. Piveteau, Paris

A. Remane, Kiel

A. H. Schultz, Zurich

D. Starck, Frankfurt am Main

W. L. Straus, Jr., Baltimore, Md.

S. L. Washburn, San Francisco, Calif.

H. Zapfe, Wien

S. Zuckerman, Birmingham

$13 / 4 \Lambda \quad$ S.Karger

SOTK Basel $\cdot$ München $\cdot$ Paris $\cdot$ London $\cdot$ New York $\cdot$ Sydney

S. Karger · Basel · München · Paris · London · New York · Sydney Arnold-Böcklin-Strasse 25, CH-4000 Basel 11 (Switzerland)

All rights, including that of translation into other languages, reserved. Photomechanic reproduction (photocopy, microcopy) of this volume or parts thereof without special permission of the publishers is prohibited.

(C) Copyright 1971 by S. Karger AG, Verlag für Medizin und Naturwissenschaften, Basel Printed in Switzerland by Schellenberg-Druck, Pfäffikon ZH

Contents

Abplanalp, P.: The Neuroanatomical Organization of the Visual System in the Tree

Shrew 1

Bousset, J.: vide Hladik, C. M.

Buss, D. H. and Hamner, J. E. 111: Supernumerary Nipples in the Baboon (Papio cynocephalus) 153

Dail, W. G.; Norvell, J. E., and Haines, D. E.: The Intrinsic Adrenergic and 
Cholinergic Innervation of the Genitalia of Galago and Tupaia. The Penis 221

David, G. F. X. and Ramaswami, L. S.: The Pituitary Gland of the North Indian

Langur (Preẃytis entellus entellus Dufrèsne,) 52

Delort-Laval, J.: vide Hladik, C. M.

De Vos, A. and Omar, A.: Territories and Movements of Sykes Monkeys (Cercopi-

thecus mitis kolbi Neumanj in Kenya 196

De Vos, A.: vide Omar, A.

Dukelow, W. R.: vide Jewett, D. A.

Egozcue, J.: Evolution of the Marked Chromosomes of Primates. Experimental

Evidence for Pericentric Inversion 276

Ehrlich, Annette: vide Fobes, J. L.

Felsenfeld, O. and Wolf, R. H.: Serological Reactions with Treponemal Antigens in

Nonhuman Primates and the Natural History of Treponematosis in Man 294

Fobes, J. L. and Ehrlich, Annette: Glucose Preferences in the Greater Galago

(Galago crassícaudatus) and Slow Loris (Nycticebus coucang) 306

Hafez, E. S. E.: vide Kanagawa, H.

Haines, D. E.: vide Dail, W. G.

Hamner, J. E. 111: vide Buss, D. H.

Hanby, Jeannette P.; Robertson, L. T., and Phoen $\gamma$ x, C. H.: The Sexual Behavior

of a Confined Troop of Japanese Macaques 123

Hladik, A.: vide Hladik, C. M.

Hladik, C. M.; Hladik, A.; Bousset, J.; Valdebouze, P.; Viroben, G. et Delort-Laval, J.: Le

regime alimentaire des Primates de $\Gamma$ île de Barro-Colorado (Panama). Résultats des analyses

quantitatives - The Diet of the Primates on the Barro-Colorado Island (Panama) - . 85

Hoffman, R. A.: vide Hubbard, R. W.

Hubbard, R. W.; Hoffman, R. A., and Jenkins, D.: Tissue Enzyme Studies in

Macaca nemestrina Monkeys 282

Jenkins, D.: vide Hubbard, R. W.

Jewett, D. A. and Dukelow, W. R.: Follicular Morphology in Macaca fascicularis

(with 2 color plates) 216

Kanagasuntheram, R.: vide Loo, S. K.

Kanagawa, H.; Hafez, E. S. E., and Nawar, M.: The Chromosomes of the Crab-

eating Macaque (Macaca fascicularis) 270

Contents

Kantaria, P. M.: The Blood Supply of the Heart in Different Monkey Species. On

the Types of Myocardial Blood Supply 231

Lewis, O. J.: The Contrasting Morphology Found in the Wrist Joints of Semi-

brachiating Monkeys and Brachiating Apes 248

Loo, S. K. and Kanagasuntheram, R.: The Nasal Fossa of Tupaia glis and Nyctí-

cebus coucang 74

Moore, Jean K. and Moore, R. Y.: A Comparative Study of the Superior Olivary

Complex in the Primate Brain 35

Moore, R. Y.: vide Moore, Jean K.

Nawar, M.: vide Kanagawa, $H$.

Norvell, J. E.: vide Dail, W. G.

Omar, A. and DeVos, A.: The Annual Reproductive Cycle of an African Monkey 
(Cercopithecus mitis kolbi NeumanJ 206

Omar, A.: vide DeVos, A.

Phoenix, C. H.: vide Hanby, Jeannette P.

Ramaswami, L. S.: vide David, G. F. X.

Ransom, B. S.: vide Ransom, T. W.

Ransom, T. W. and Ransom, B. S.: Adult Male-Infant Relations among Baboons

(Papío anubis) 179

Robertson, L. T.: vide Hanby, Jeannette P.

Rumbaugh, D. M. and Steinmetz, G. T.: Discrimination Reversal Skills of the

Lowland Gorilla (Gorilla g. gorilla) 144

Saayman, G. S.: Grooming Behaviour in a Troop of Free-ranging Chacma Baboons

(Papio ursinus) 161

Steinmetz, G. T.: vide Rumbaugh, D. M.

Tattersall, I.: Revision of the Subfossil Indriinae 257

Valdebouze, P.: vide Hladik, C. M. Viroben, G.: vide Hladik, C. M. Wolf, R. H.: vide Felsenfeld, O.

Book Reviews · Buchbesprechungen · Livres nouveaux $\quad 159,312$ 